Katri Vuola

\title{
WOOD SPECIES AND THE QUESTION OF ORIGIN: REASSESSING THE SCULPTURE PRODUCTION IN THE DIOCESE OF TURKU (ÅBO) DURING THE 14TH CENTURY
}

It was oak that was preferred abroad, sometimes limewood, for such carvings. In the Nordic countries birch and other of our common wood species were used for this, yet, in the old account books one can also find remarks on the imports of wood during the 15th and 16th centuries, possibly for the material of the artworks, for the most part possibly mainly for the chairs and chests in the castles as well as bishops' seats and choir screens, e.g. for the needs of the churches. ${ }^{1}$

This short outline of the wood use in medieval ecclesiastical sculpture and church furnishing is included in Emil Nervander's (1840-1914) essay on church art in Finland, published in a series of Kansanvalistusseuran toimituksia (1887), a journal aimed for the education of the public. In addition to being a writer, Nervander was the planner, and on some occasions also the leader of art historical

DOI: https://doi.org/10.12697/BJAH.2019.18.02

1 Emil Nervander, Kirkollisesta taiteesta Suomessa keskiaikana. Ensimmäinen vihko. Kansanvalistusseuran toimituksia LXXIII (Helsinki, 1887), 27. The translation of the citation from Swedish into English is by the author. 
excursions to rural churches in Finland, organized by The Finnish Antiquarian Society from the 1870s to the early 1900s. He had been one of the most active initiators of the society, and he was the first to systematically work on the preservation and popularization of medieval cultural heritage in Finland. ${ }^{2}$ Documented observations on the wood species of the medieval sculptures, catalogued during the excursions, indicate that the materiality of the sculptures was taken into account in the early phase of antiquarian research. ${ }^{3}$

During the 20th century, the assumptions concerning the wood species and their use as indicators of origin remained basically the same as sketched by Nervander in the 1880s. The use of birch for sculpting, together with a certain clumsiness and simplification of the form, as well as stylistic conservativeness, were usually understood as proofs of Finnish origin. ${ }^{4}$ These features were also sometimes considered to express the temper and nature of the nation in an honest manner. ${ }^{5}$ Nervander's hypothesis concerning the role of birch in ecclesiastical sculpture is still often applied in overviews of medieval sculpture or wood use culture in Finland. The little known results of microscopic wood analysis conducted over the past few decades help to form a new picture. These results discussed in this article show that birch (Betula) is rarely, if ever, found among the sculptures. It seems rather that in addition to oak, alder (Alnus) and lime (Tilia) were commonly used for sculpting a human figure.

My aim in this article is to present a new hypothesis of wood use tradition in sculpture in the medieval diocese of Turku (Åbo), the

2 Leena Valkeapää, Vapaa kuin lintu. Emil Nervanderin elämä. Taidehistoriallisia tutkimuksia Konsthistoriska studier 47 (Helsinki: Suomen taidehistoriallinen seura, 2015), 98-100, 108, 118 119; Leena Valkeapää, 'Suomen muinaismui

3 See e.g. the notes in the margins of the list of the sculptures in Raisio Church in 1874 , written down by Eliel Aspelin during the visit of the Second Art Historical Excursion of The Finnish Antiquarian Society. Microfilms, Finnish Heritage Agency (FHA), Archive of The Finnish Antiquarian Society.

4 See Carl Axel Nordman, Medeltida skulptur i Finland. Suomen Muinaismuistoyhdistyksen Aikakauskirja, 62 (1965), e.g. 118, 222-224, 236; Konsten $i$ Finland: Från medeltid till nutid, ed. by Bengt von Bonsdorff (Esbo: Schildt, 1998), 45; Seija A. Niemi, Koivu, Suomen kansallispuu (Helsinki: Minerva Kustannus Oy, 2015), 137.

5 See e.g. Carl Axel Nordman, Medeltida skulptur $i$ Nationalmuseum. Konst och konsthantverk

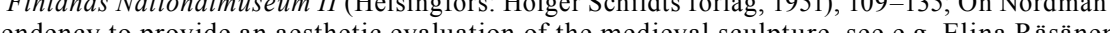
Ruumiillinen esine, materiaalinen suku. Tutkimus Pyhä Anu itse kolmantena -qiheisista keskiaja puuveistoksista Suomessa. Suomen Muinaismuistoyhdistyksen Aikakauskirja, 116 (2009), 218; Katri Vuola 'Lundomästaren - Från anonymitet till en konstruerad identitet', Finskt Museum 2013-2015, Finska Fornminnesföreningens Tidskrift (2016), 81-104, 90, 94.
Eastern part of the Swedish kingdom in the Middle Ages. I will do this by combining art historical methods and those pertaining to the natural sciences. This means that I observe the sculptures and analyse their material, style and form, as well as include the new and corrected results regarding the wood species. My approach takes into account the supposed emergence of local sculpture production in the diocese in the first half of the 14th century, and its relation to imported sculptures. I will additionally assess the wood choices from the perspective of availability in the diocese and the suitability of the wood species for carving (workability), as well as the qualities related to the endurance of the wood. ${ }^{6}$

In this article, I subscribe to the understanding of art historical practice as a multifaceted process - including what is now called technical art history, namely focusing on materials and approaching the objects under scrutiny by means of scientific methods. In recen decades we have witnessed a paradigmatic change, the 'material turn', which has many applications also in art history, including, among other things, the renewed interest in materials, discussions around the agency of objects, and stressing the life of objects. ${ }^{7}$ Above all technical art history has been incorporated into classical art historical methods and into iconographical and formal analyses.

The research material of my analysis consists of 134 sculptures used in the Catholic liturgy and devotions in the diocese of Turku during the 13th and 14th centuries. This is c. 18 percent of the remaining medieval sculptures in Finland. These sculptures depict the Virgin Mary and Child, Christ on the Cross and as Resurrected, as well as different saints, many of which are today undefinable due to the loss of any identifying attributes. ${ }^{8}$ Also, the structures framing and enclosing

6 This article is a part of my doctoral research project (University of Helsinki) funded by the Kone Foundation, as well as of the project 'Carving Out Transformations - Wood Use in North-Eastern Europe, 1100-1600', based at the University of Turku, Finland, and funded by the Academy of Finland (Decision no. 315540). I am grateful to my supervisor Dr. Elina Räsänen (University of Helsinki) for her reading of this article and her always constructive support on language and academic writing in general; a great number of experts in their fields, including colleagues and friends as well as the personnel of the museums and archives I have collaborated with during the research. They are mentioned in the notes in different contexts.

7 See e.g. Michael Yonan, 'Toward a Fusion of Art History and Material Culture Studies', West 86th, Vol.18, No. 2 (2011), 232-248.

8 The 134 sculptures stem from 57 churches. Today 81 of the sculptures are administered by professional museums or they are stored in premises administered by the congregations or local is still located in 40 churches in Southern and Western Finland. Three sculptures have been destroyed and their analysis is based only on archived documents. 
these figures - tabernacles, dorsali and crosses - are more often lost than have survived, and thus are given a lesser role in this article.

The starting points of my research were my own observations, as well as the many remarks made during the past decades in the connection of the research and conservation of the supposed birch sculptures. ${ }^{9}$ My research has benefitted from the wood anatomical reports (1995, 1997 and 1999) in the archives of the conservation department at the National Museum of Finland. In order to obtain more information, I organized the wood anatomical analysis of four sculptures at the Museum Centre of Turku (in 2015) and one at the Tampere Museums (in 2019). In addition, I have observed, documented and photographed in situ almost all of the approximately 130 sculptures included in my research material. Because of the fragility of the material, this has been carried out together with researchers and conservators of the museums and personnel of the congregations. ${ }^{10}$ The identification of wood species in this study is based both on ocular observation and microscopic analysis. Both methods have their limitations; when observing the wood by eye the evaluator's experience and expectations affect the results. In addition, wear and tear, or even layers of dust and dirt on a sculpture can affect the interpretation. The polychromy may conceal the wood of the sculpture completely, as is often the case with crucifixes. Furthermore, every piece of wood has its individual material qualities. To increase the reliability of the identifications, the analyses were carried out collectively and together with professionals from various fields conservators, artists, artisans and art historians. ${ }^{11}$ The microscopic

9 See Katri Vuola, 'Puusta vuollut, värillä elävöitetyt', Pyhät ja pakanat. Ihmisyyden kuvia, ed. by Sanna Teittinen (Helsinki: Suomen kansallismuseo, 2017), 30-41; Räsänen, Ruumiillinen esine, materiaalinen suku, 70, 75; Suvi Leukumaavaara, 'Ein polychromes Kruzifx aus Finnland. Besondere Materialien und Techniken, Restaurierung' Restauro, Zeitschrift für Kunstechniken

10 I would like to thank especially the personnel of the National Museum of Finland (Helsinki), the Turku Museum Centre, the Tampere Museums, the Swedish History Museum (Stockholm), the Gotland Museum (Visby) as well as the personnel in the many congregations I visited during my research for their help as well as for the many fruitful discussions I was able to have in the course of this research. I also owe a special debt to conservator Henni Reijonen MA, conservato Jukkapekka Etäsalo and intendant Heidi Rajala for their tireless help in locating and documenting the sculptures and archival material. In addition, many of my colleagues, friends and relative ead the research by joining in with the observation and documentation of the sculptures in the field.

11 Here I am particularly thankful to Dr. Mia Lempiäinen-Avci (University of Turku) for the microscopic analysis conducted for this article as well as to sculptor, Maija Helasvuo MFA (Hyvinkää), and conservators Hanna Tuokila (Tampere Museums), Sari Selkee (Turku Museum Centre) and Raimo Savinainen (National Museum of Finland) for sharing their expertise concerning wood as sculpting material and for the many discussions on problematics concerning the identification of wood species by eye. analysis of the wood is based on the 'subjective eye'; however, its accuracy is based on the identification of the cellular structure that is distinctive of a certain wood species. The downside of this method is its invasiveness, as it usually requires an extraction of a sample from the object. ${ }^{12}$ Furthermore, distinguishing sub-species from each other with this method is often impossible: the wood anatomical structure is the same, for example, for both the grey alder (Alnus incana) and the black alder (Alnus glutinosa)..$^{13}$

The deep-rooted idea of birch as a widely used material for figure carving in local medieval workshops was emitted and even strengthened by art historian and archaeologist C. A. Nordman His monograph, Medeltida skulptur i Finland (1965), in which almost all the surviving medieval sculptures and altarpieces in Finland are described, measured and dated, is widely cited. ${ }^{14}$ The vast task included the definition of the wood species, along with black and white photography of almost all the objects. Nordman's emphasis was on the collections of the National Museum of Finland, which he headed as the State Archaeologist 1936-1959. ${ }^{15}$ Nordman's work benefited from the expertise of the conservators of the museum: Oskari Niemi (1886-1964) and his successor Veikko Kiljunen (1927-2001), especially concerning the materials used for the figures. ${ }^{16}$ Interestingly, the wood species of all the sculptures in the museum's collection were further defined systematically and comprehensively by Professor Matti Jalava (1893-1975) from the Department of Wood Technology at the

12 The wood species (alder) of the Virgin Mary and Child from Vanaja (Inv. nr. TM190:13) was, however, defined without sampling by conservator Hanna Tuokila, who used reflected light microscopy for examining the surface of the sculpture. This method is, however not as reliable as the analysis of the cellular structure of a specimen would produce. Hanna Tuokila: E-mail message to the author, 4 October 2019.

13 Kurt Fagerstedt, Kerttu Pellinen, Pekka Saranpää, Tuuli Timonen, Mikä puu - mistä puusta (Helsinki: Helsinki University Press, 2005), 116.

14 For Nordman as an art historian, see Elina Räsänen, 'Reviewing Research of Medieval Wood Sculptures. The Encounter of Olga Alice Nygren and Carl Axel Nordman with the Crowned Sain Ann', The Shaping of Art History in Finland. Taidehistoriallisia tutkimuksia, 36 (2007), 214227; Räsänen, Ruumiillinen esine, materiaalinen suku, e.g. 29-31; Carl F. Meinander, Carl Axel Nordman, Skrifter utgivna av Svenska litteratursällskapet i Finland, 569. Levnadsteckninga 11 ( 1991), 122-130; Vuola, 'Lundomästaren - Från anonymitet till en konstruerad identitet'.

15 Meinander, Carl Axel Nordman, 122-130.

16 On the careers of Niemi and Kiljunen, see Henni Reijonen, 'Suomalaisten museokokoelmien konservoinnin historiaa: kokoelmien hoito ja säilyttäminen Suomen Taideyhdistyksessä ja Muinaisticteelhisessa toimikus Suomalaisen Kirjallisuuden Seura, 2010), 301-302, 304, 308 (Niemi), 306, 308 (Kiljunen). 
University of Helsinki. ${ }^{17}$ The results - presumably gained exclusively by ocular observation - were compiled into a typed list of c. 200 wooden sculptures, which reveals that Jalava defines almost all the sculptures other than oak as made of birch wood..$^{18}$ Some of these definitions as birch have later been corrected by hand, probably by Veikko Kiljunen, to limewood. ${ }^{19}$ The notes in the Medeltida skulptur $i$ Finland indicate that consensus was not always achieved between conservator-artists - with practical knowledge of the materials, and Professor Jalava as the proponent of the academic world. The ambitious project, which probably can be interpreted as an effort to achieve scientific objectivity, basically resulted in the confirmation of the 19th century hypothesis of the 'Finnishness' of birch.

Following the introduction, I will in the next chapter describe the natural environment in the diocese of Turku and the surrounding areas during the Middle Ages by briefly discussing the wood resources and the distribution of different wood species in the area. I then focus my analysis on the supposed birch sculptures and suggest instead 'new' wood species - pinewood, alder and limewood. I also discuss the individual wood species' suitability for carving. A more profound form and style analysis is given to the sculptures belonging to the 'oeuvre' or 'artistic production' attributed to the Master of Lieto. I have earlier demonstrated that the created actually form a rather heterogeneous group regarding form, technology and material; here I will develop this idea further. ${ }^{20}$ I then discuss the results of the analysis in the context of the comparative material surviving in other Nordic countries. Finally, I assess the limitations and possibilities of the methods used in my research as well as its research significance for understanding the relation of the imported ecclesiastical sculptures to the emergence of local sculpture production in Finland.

17 Jalava was Adjunct Professor (1939-1948) and Professor (1948-1960) in Wood Technology, see Helsingin yliopiston opettaja- ja virkamiesluettelo 1918-2000. Yliopistomatrikkelit (Helsingi yliopisto, https://urly.fi/lfob [accessed 18 June 2019]).

18 Kansallismuseon keskiaikaisten pyhimystenkuvien puulajit prof. Jalavan määrittelyn mukaan 11.4.1949. Konserv. V. Kiljusen moniste. National Museum of Finland, Conservation Archive.

19 Henni Reijonen: E-mail message to the author, 19 June 2019.

20 See Katri Vuola, “"Varsinaista kuvanveistoa voi tuskin sanoa alkuunkaan olleen.” Vai oliko sittenkin?', Ristin ja Olavin kansaa. Keskiajan usko ja kirkko Hämeessä ja Satakunnassa, Tampereen museoiden julkaisuja 55, ed. by Marja-Liisa Linder, Marjo-Riitta Saloniemi, Christia Krötzl (Tampere: Tampereen museot, 2000), 101-109; Katri Vuola, Seisovat ja istuvat veistokse ns. Liedon mestarin tuotannossa. Dokumentointi, unpublished Master's Thesis (University of Turku, 1997)

\section{THE NATURAL ENVIRONMENT AND THE AVAILABILITY} OF THE WOOD SPECIES IN THE DIOCESE OF TURKU

The pattern of distribution of wood species in Finland, geographically situated in Fennoscandia, is assumed to have been approximately the same during the Middle Ages as it is today, ${ }^{21}$ even though agriculture, industrialization and population growth have decreased the total area of forests (now about 76 percent of the country). ${ }^{22}$ Finland belongs to the boreal coniferous forest zone, which also extends to the neighbouring Scandinavia and Russia. There are around thirty indigenous tree species: the most common of them are pine (Pinus sylvestris), spruce (Picea abies), and birch (Betula pendula and Betula pubescens), the latter predominating about 10 percent of the forests. Oak (Quercus robur) only grows in the hemiboreal zone of the SouthWestern coastal part of Finland and in the archipelago, whereas small-leaved lime (Tilia cordata) can be found in the Southern part of present-day Finland - although it is more prevalent inland. From the point of view of the subject of this article, it is important to acknowledge that the growth areas of wood species that are naturally present in Finland are not restricted to the present or former borders of the Finnish territory: e.g. pine, spruce, birch, oak, lime, alder (Alnus), and aspen (Populus) can be found throughout the Baltic Sea Area. ${ }^{23}$

\section{SCULPTURES CARVED FROM PINEWOOD}

Only two sculptures in the research material have earlier been defined as carved from pine: a standing female saint ${ }^{24}$ from Kisko church,

21 Henri Väre: E-mail message to the author, 30 June 2014

22 'The most extensive forest cover in Europe', The Natural Research Institute Finland, https://urly.fi/l fof (accessed 9 June 2019)

23 On the tree species in Finland, see 'Tree species', Luke Natural Research Institute Finland, https://urly.fi//1fod; on the growth areas in Europe, see 'Species', European Forests Genetic sesources Programme, https://urly.fi// foe; 'Small-leaved Lime', NatureGate, https://urly.fil/lfoi, https://urly fi/lfok: 'Quercus Robur. Pedunculate oak', European Forests Genetics Resources Programme, https://urly.fi//foc (all the web pages accessed 9 June 2019).

24 The sculpture is kept at the present in the administrative building of the Salo congregation. It is hollowed-out and there is a hole cut (?) in the head that reaches the cavity at the height of the shoulders. The hole is filled with three wooden plugs. Height $93 \mathrm{~cm}$. See also Nordman, Medeltida skulptur i Finland, 235. 
and the standing Virgin Mary ${ }^{25}$ (now without the Christ Child) in the Pertteli local museum. These sculptures, dated to the last decades of the 14th century, are severely worn and only diminutive fragments of their polychromy are left. The saint in Kisko - possibly St. Margaret - is standing on a small figure (a dragon?) of which only the contours outlined on the surface of the pedestal are visible. ${ }^{26}$ The saint has a somewhat cone-shaped form with narrow shoulders, a long dress, and a robe drawn across the chest to the right arm. The saint has worn a crown. Rather than having a contrapposto pose typical of the High and Late Medieval sculpture, the posture of the figure is rigid and frontal. The dress and the robe, however, fall naturally and gracefully towards the ground. The folds are exceedingly flat and somewhat angular - features which seem to reflect the limitations of pinewood as carving material: pine is long-grained and has a coarse surface. ${ }^{27}$ The sculpture can also be dated later because the representations of Saint Margaret became more common in the region at the beginning of the 15th century. The pinewood as such does not point in any particular direction, at least it does not seem to have any counterparts either in the Finnish or in the Swedish/Norwegian area, where pinewood was used in local workshops. Of the seventeen sculptures depicting the Norwegian saintly king Olaf, seven have earlier been identified as made of birch. Two of them seem instead to be made from red pine, namely the enthroned Saint Olaf from Padasjoki ${ }^{28}$, and the enthroned Saint Olaf from an unknown church $^{29}$; both are now in the collection of the National Museum of Finland. ${ }^{30}$ Red pine is the term used to refer to the hardwood of an old pine or deadwood: characteristic of the wood is its intense redness. The small and delicately carved enthroned St. Olaf from Padasjoki has a

25 On determining the wood species, see Nordman, Medeltida skulptur $i$ Finland, 224. The display of the sculpture in the Pertteli local museum situated in an old parish granary did no allow a close examination of the sculpture during my visit in 2014 .

26 Nordman, Medeltida skulptur i Finland, 235; The sculpture (height $93 \mathrm{~cm}$ ) is hollowed out. It is located in the archive room of the Salo parish, where it was relocated from the boiler room of the Kisko vicary by property manager Kai Fagerström.

27 See e.g. Fagerstedt et al., Mikä puu - mistä puusta.

28 Inv. nr. H3613:2, height $50 \mathrm{~cm}$. Nordman, Medeltida skulptur i Finland, 134.

29 Inv. nr. H28092:23, height $70 \mathrm{~cm}$. Ibidem, 236

30 These new wood definitions I made together with sculptor Maija Helasvuo MFA on the basis of photos taken by the author. Helsinki, 22 February 2019 well preserved, and partly post-medieval, polychromy, with the seat painted in marble imitation. King Olaf is sitting in a frontal position, dressed in a long red tunic which, nevertheless, leaves the ankles and feet with pointed shoes exposed. The sculpture differs in many respects from the other sculptures of the enthroned St. Olaf in the diocese, and in my mind seems to belong to the tradition of High Gothic sculptures in Norway and Sweden, such as the enthroned St. Olaf from Tylldalen, Hedmark County ${ }^{31}$, dating from the first half of the 13th century. The sculpture is massive (not hollowed-out) and the back is unpainted. The separately carved hands with the attributes as well as the crown have disappeared. The other sculpture of St. Ola is similarly frontal and massive; in addition, the attributes and the crown are lost and the sculpture has been stripped of almost of all of its colours (Fig. 1). The three-dimensional form seems to follow the cylinder-like form of a tree trunk, giving the impression of the figure having been carved from stone. The type of the belt guided Nordman to date it to the end of the 14th century, but based on its striking similarity with the sculpture of St. Olaf from Grong, North Trøndelag ${ }^{32}$, I would suggest a new dating: the first third of the fourteenth century. The sculpture has possibly been reworked later. On the basis of analysis of the style and material, both sculptures presented above may have been carved in Norway or in NorthWestern Sweden, instead of the previously supposed Finland or Gotland. Interestingly, like many supposed St. Olaf sculptures in Finland, both of these examples lack the underlying dragon or a human figure usually found in the depictions of the Norwegian saintly king. ${ }^{33}$

At present, then, there is no evidence that the good availability of softwood (such as pine) in the region would have resulted in its use

31 Inv. nr. 10364, Nationalmuseet, Copenhagen, height $148 \mathrm{~cm}$. See Martin Blindheim, Gothic Painted Wr. I0364, Nationalmused, Copentagen, height $148 \mathrm{~cm}$ See Mathe is made of pine (pinus). 32 Inv. nr. T1946 Vitenskapsmuseet, Trondheim, height $120 \mathrm{~cm}$. See Blindheim, Gothic Painted Wooden Sculpture in Norway 1220-1350, 210-211. The sculpture is made of pine (pinus)

33 See Katri Vuola, 'Medieval Wooden Sculpture of an Unknown Saint from Nousiainen:from Materials to Meaning', Mirator, 19 (1) (2018). Proceedings of the Conference held in Helsinki, 1-2 December 2016, ed. by Reima Välimäki, Karolina Kouvola(Helsinki: Glossary, 2018), 43-66. See: https://journal.fi/mirator/article/view/69101/31330 (accessed 9 June 2019). 


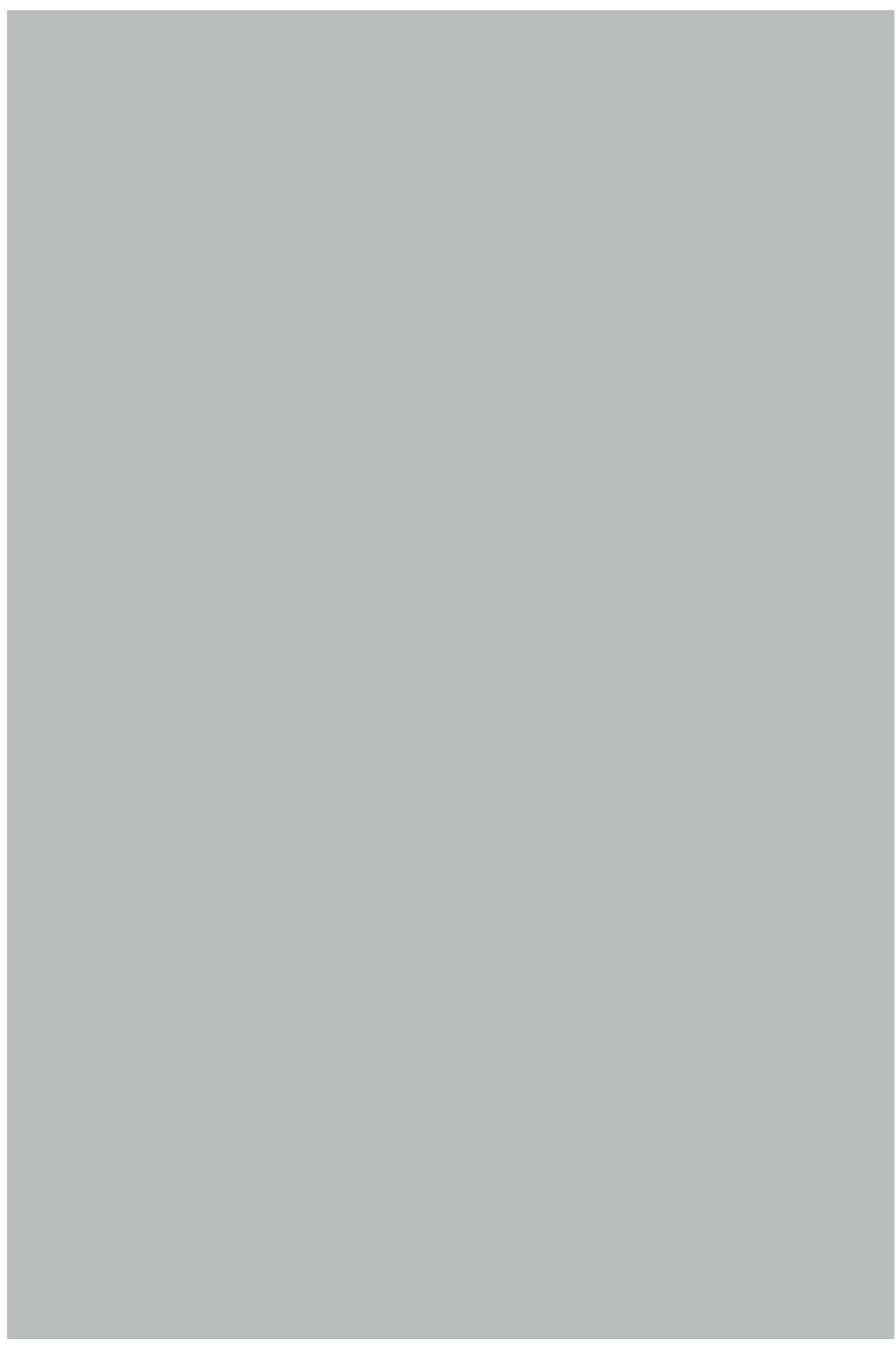

FIG. 1. ST. OLOF FROM AN UNKNOWN CHURCH. RED PINE. FIRST HALF OF THE 14TH CENTURY NATIONAL MUSEUM OF FINLAND. PHOTO: ILARI JÄRVINEN, FINNISH HERITAGE AGENCY. in local workshops. However, in Norway the use of pinewood for sculpting figures was common, even though it was mainly limited to the mountainous areas, as oak was preferred in the valleys; this suggests that the workshops used the wood that surrounded them. ${ }^{34}$ In Sweden, the use of pine was limited to the Western and Northern areas, and to the sculptures carved in an Anglo-Norwegian style. ${ }^{35}$ Pine has disadvantages - it is long-grained and coarse, it produces resin and it cracks and splits easily during the drying process. ${ }^{36}$ Pine planks and panels were, nevertheless, commonly used in the Nordic countries for the beams of the crosses of the crucifixes, as well as for the panels, pedestals, supporting structures and decorations of the tabernacles and altarpieces. ${ }^{37}$

\section{FROM OAK TO ALDER AND LIMEWOOD}

In the following, I give examples of sculptures carved from alder. However, I wish to emphasize that even though the craftsmen were probably trained within a certain wood use culture, many of the sculptures in my research material bear witness to the economic use of smaller wood pieces "lying around in the workshop". For example, soft wood - usually pinewood - was fairly often used for small details or parts that are invisible to the beholder, such as the backboards of the hollowed-out sculptures; e.g. for the monumentalsize Virgin Mary and Child from Rusko ${ }^{38}$. The figure, which is one of the first examples of a standing Virgin in the remaining material, is

34 Blindheim, Gothic Painted Wooden Sculpture in Norway 1220-1350, 18

35 Ibidem. Similarly, Tångeberg relates the use of beech to sculptures possibly imported from Denmark. Peter Tangeberg, Mittelalterliche Holzskulpturen und Altarschreine in Schweden: Akademien, 1986), 18

36 Fagerstedt et al., Mikä puu - mistä puusta, 74. 37 If it is the original part of the construction, as suggested by Dr. Asa Ringbom, the piece
of pine felled in 1247 seems to be indisputable evidence for the local assembling of the crucifix in Saltvik, Åland, supported by the fact that aspen - rarely used for crosses or sculptures has been used for the beams of the cross. Christina Remmer \& Åsa Ringbom, Alands kyrkor Vol. 2, Saltvik (2000), 195.

38 Inv. nr. TM4762, height $188 \mathrm{~cm}$. See also Nordman Medeltida skulptur i Finland, 22. 
itself carved from alder, instead of the formerly alleged birch..$^{39}$ The Christ Child, who has a straight, elongated body, sits in an upright position on the right arm of his mother. The disproportionally small heads of both of the figures are most probably results of a recarving of the sculpture: the style and features of the narrow, mildly smiling faces, small double chins and curls framing the cheeks could point e.g. to East-Prussia (Northern Poland) - I would suggest that the upper part of the sculpture has been re-carved during the first part of the 15th century. The carver could have been a travelling craftsman, rather than the sculpture having been manufactured locally some fifty years earlier and sent to a workshop located on the southern coast of the Baltic Sea. ${ }^{40}$ If we consider that the use of alder as the main material points to a local workshop, then also the fragments of red colour on the robe with rhombus-shaped decorations made of tin or silver leaf with yellowish glaze (instead of using real gold) may point to favouring material that was easily available, and therefore not so expensive. Similar kinds of decorations can be found in some other 14th century locally produced sculptures, which will be dealt with next.

Other examples of sculpture that turned out to be of alder instead of birch are the enthroned Saint Olaf in the Luvia church (dated to the turn of the 15th century), ${ }^{41}$ and the female saint from Lieto (last third of the 14th century). ${ }^{42}$ Both have crowns of limewood. Saint Olaf is depicted seated and in a rigid, frontal posture typical of

39 For the microscopic analysis conducted for this article, see Mia Lempiäinen-Avci, Keskiaikaisten veistosten punaineen määritys. Tutkimusraportti 2015. University of Turku, Department of Biology, Herbarium / Archaeobotanical laboratory; the wood species of the backboard was determined as pine by ocular observation. Pine can also be found in the backboard in the crucifixes of Sund, Aland (second part of the 13th century), Nummi (end of the 14th ce a a d a (167-194.

40 I have compared the Virgin to sculptures originating from larger altarpieces: a small female saint from Taivassalo (H2717:5), the Virgin Mary from Tyrvaa (H1714), Pieta from Perniö (H1186:4). To this "style group" may also belong the Virgin Mary from Somero (H1180:2) and the Anna Selbdritt from Hattula church, see Rasanen, Ruumiillinen esine, materiaaline suku, 196-197.

41 Taru Väisänen, Luvian Pyhä Olavi, unpublished diploma work (Vantaa: Metropolia, 2010). The wood anatomical analysis for this study was conducted by Seppo Zetterberg: Nordman, Medeltida skulptur i Finland, 235.

42 Inv. nr. TM4828, height $100 \mathrm{~cm}$, see Nordman 1965, 209. Wood anatomical study by Dr. Mia Lempiäninu-Avci, see Keskiaikatsten verst the late 13th century High Gothic sculptures in Scandinavia. The late date of its manufacture is based on the type of the belt and the model of the exceptionally well-preserved crown. ${ }^{43}$ Nordman has interpreted these features as pointing to a local sculptor who worked in a Gotlandic style - a style he never clearly explains in his analysis. ${ }^{44}$ Current scholarship stresses that the local production of sculptures and altarpieces in Gotland was influenced by art works imported from Westphalia, Flanders, and even England. Foreign craftsmen probably also worked on the island. Therefore, it is difficult to point out any specific stylistic features which could allude to Gotland. ${ }^{45}$ On the basis of the surviving material, the use of alder seems to have been unusual or even unknown on the island; instead, oak, and sometimes limewood, was favoured. ${ }^{46}$ The enthroned Saint Olaf from Rusko, or a similar kind of imported sculpture, may have served as a model for the carver of the Olaf in the Luvia sculpture; but instead of the Rusko sculpture being of Gotlandic origin, as suggested by Nordman and his Swedish colleagues, it may equally likely have been imported directly from Germany. ${ }^{47}$

In optimal circumstances, tree-ring analysis can be used to determine the date and origin of the material of sculptures carved from oak and pine. ${ }^{48}$ Other wood species growing in Fennoscandia and around the Baltic Sea do not have these qualities, and therefore the

43 Nordman, Medeltida skulptur i Finland, 235.

44 Ibidem.

45 On the possible relation between the (now often lost) imported sculptures and altarpieces and the still remaining sculptures and altarpieces supposed to be manufactured locally, see Peter Tångeberg, Retabel und Altarschreine des 14. Jahrhunderts: Schwedische Altarausstattungen in ihrem europäischen Konstext, Juliane von Fircks, Skulptur im Sudlichen Ostseeraum. Stile, Werkstätten und Auftraggeber im 13. Jahrhundert. Studien zur Internationalen Architekturund Kunstgeschichte 90 (Petersberg: Michael Imhof Verlag, 2012).

46 As rare examples of sculptures from other wood species than oak are the female saint from Hörsne (inv.nr. DB864 Gotlands fornsal, Visby) and the apostle from Hejdeby (inv.nr. DB904 Gotlands fornsal, Visby). See e.g. Carina Jacobsson, Höggotisk träskulptur i Gamla Linköping stift (Visby: Ödin, 1995), 113 and 293.

47 Nordman, Medeltida skulptur i Finland, 111-112.

48 Tree-ring analysis can be applied to dendrochronology (tree-ring dating) and to determine the provenance of the timber - oak, pine or spruce. See e.g. 'Dendrochronology an provenance determination', dendro.dk, https://urly.fi//fq6 (accessed 19 June 2019); Laboratory of Dendrochronology, Department of Forest Sciences Faculty of Science and Forestry, University of Eastern Finland, Joensuu, https://urly.fi/lfqa (accessed 19 June 2019); I am grateful to Dr. Markus Hiekkanen for sharing the information concerning the results of the dendrochronological analysis of medieval sculpture in his research project funded by the Academy of Finland Medieval Churches and their Sites as Centres of Religious and Secular Administration in Parish Communities in Finland from the 13th to the 20th century (2000-2005). 
traditional art historical methods, such as formal and iconographical analysis, have to be included in the research. Out of the 134 sculptures belonging to the research material, 45 percent have been defined as made of oak. Oak is relatively easy to identify without sampling, as the growth rings are visible and the grain lines are broad, and in a certain cut of the wood there are flame-like flecks. The colour of the wood is usually light brown, but the shade of brown seems to vary considerably, which at least partly depends on the later handlings of the surface (grinding, polishing, waxing). ${ }^{49}$ Tree-ring analysis conducted on the Finnish material has shown that many of the few 13 th century or early 14 th century sculptures were felled in and most probably imported from Northern Germany. ${ }^{50}$ As is well known, in the prosperous Hanseatic town of Lübeck oak was an obligatory wood choice for craftsmen who specialized in manufacturing sculptures and altarpieces: its hardness and durability guaranteed quality. ${ }^{51}$ In contrast, the craftsmen in the North were supposedly less bound by guild regulations, and instead guided by the availability and inexpensiveness of the wood, as well as the wood's suitability for carving a human figure.

Whether oak was imported into Finland to be used in artworks or whether local oak was used is not well known. There is a proportionally large number of oak sculptures in Finland that have not yet been analysed, or which have not yielded any results regarding the dating or the place of the felling of the wood..$^{52}$ I will,

49 There are hundreds of subspecies for oak, but in the Baltic Sea area common oak (Quercus robur) is dominant; sessile oak (Quercus petraea) is more southern and only grows in Poland, Germany, and on the coastal areas of Southern Sweden. See e.g. https://urly.fi/lfoc (accessed 19 June 2019)

50 As examples of this import: The Deacon (St. Laurentius?) from Perniö dated to after 1260 see Report on the dendrochronological analysis of the sculpture "St. Laurentius" KM4362:19, September 1997. Universität Hamburg, Ordinariat für Holzbiologie. National Museum of Finland, Inv.nr. 4721), see Remmer, Ringbom, Alands kyrkor, 177-179.

51 Michael Baxandall, The Limewood Sculptors of Renaissance Germany (New Haven; London: Yale University Press, 1990), 27.

52 The success of the analysis requires a sufficient number of tree-rings and adequate reference datasets to operate with. This is why the analysis conducted by Peter Klein in 1997 of the oak sculptures attributed to the Master of Lieto (National Museum of Finland) failed to produce any results. It is, however, possible to try to re-analyse the sculptures by using current datasets. am grateful to Dr. Aoife Daly for clarification on the issue of not gaining any results, see Aoife Daly: E-mail message to the author, 1 May 2019. I also thank Conservator Sari Tuomio née Lintula (Ostrobothian Museum) and Dr. Tunti Tingen (Universily or Helsinki) for the crucial information concerning the wood anatomical and dendrochronological analysis conducted in 1995,1997 and 1999 at the museum. nevertheless, suggest that the oak sculptures in the oeuvre of the Master of Lieto - an eponym created by C. A. Nordman in the 1930s - may have served as models for the sculptures of alder and one of the limewood sculptures in the same group of sculptures. ${ }^{53}$ The oeuvre (the term being used here for operational reasons) includes five statues depicting a standing and gracefully smiling Virgin Mary with the Christ Child on her left arm. The sculptures, dated between 1320 and 1350, are from the churches of Hattula, ${ }^{54}$ Hollola (Fig. 2), ${ }^{55}$ Perniö, ${ }^{56}$ Vanaja, ${ }^{57}$ and Raisio (Fig. 3). ${ }^{58}$ The redness of the wood both in the Hattula and Hollola sculptures seems to point to alder rather than birch. ${ }^{59}$ In addition, the microscopic analysis of the wood material of the Vanaja sculpture conducted in the course of this research suggests that alder is the sculpture's (including its backboard's) main material. ${ }^{60}$ These sculptures are not carved by an inexperienced craftsman, yet Mary's posture is not quite balanced and the volumes of the draperies do not fall as naturally as in the Mary from Raisio, carved from oak. Nonetheless, the two sculptures share many details, e.g. the crossed feet of the baby Jesus can be found both in Raisio and Vanaja. Small fragments of the initial polychromy left in the Perniö sculpture as well as the well-preserved polychromy of the Virgin Mary from Hattula - very much in the same style and technique as in the previously presented Virgin from Rusko - speak of lesser investment in the finishing materials than in the case of the Raisio sculpture with real gold used for the decoration of the robe. It

53 According to the hypothesis formed by C. A. Nordman, the Master of Lieto had his workshop in Turku between 1320 and 1350 and therefore had a "school-building role" in the diocese. The hypothesis is based merely on formal and stylistic analysis. See Nordman, Medeltida skulptur anonymitet till en konstruerad identitet'.

54 Nordman, Medeltida skulptur i Finland, 157-159, 176, height $85 \mathrm{~cm}$.

55 Ibidem. Inv. nr. H2004114:1, height $83 \mathrm{~cm}$

56 Ibidem. Inv. nr. H4362:7, height $89 \mathrm{~cm}$

57 Ibidem. Inv. nr. TM190:13, height $90 \mathrm{~cm}$.

58 Ibidem. Inv. nr. H60021:2, height $88 \mathrm{~cm}$.

59 The question of the wood species of these two sculptures was discussed in 2014 and 2015 together with conservator Matti Aaltonen (National Museum). The surface of the Hollola sculpture has been whetted, probably during the 20th century, when it was still in private ownership.

60 The definition/estimation by conservator Hanna Tuokila, Tampere Museums. Hanna Tuokila E-mail message attached with a preliminary report to the author, 18 July 2019 

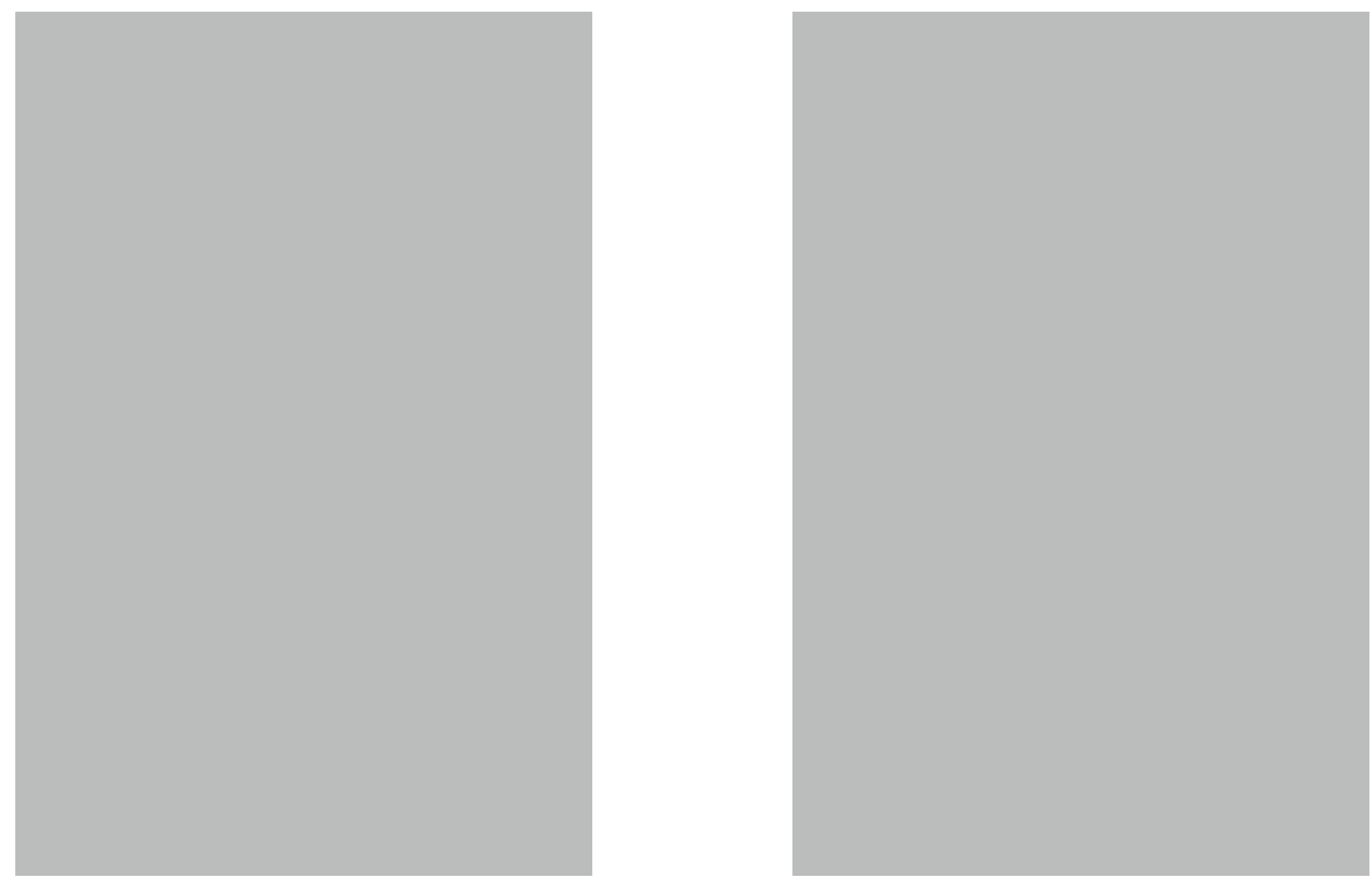
is therefore imaginable that the Virgin Mary carved from oak could have served as a model for (at least) the four other sculptures.

Interestingly, among the sculptures attributed to the Master of Lieto, the Resurrected Christ from Raisio (now in the collection of the National Museum) can also be connected to the group of the alder Virgins described above, both in terms of the wood material and the polychromy (Fig. 4). ${ }^{61}$ The Christ is carved from alder ${ }^{62}$, and I suggest that the red colouring of the robe with rhombus-shaped decorations connect the sculptures to the Virgins in Hattula ${ }^{63}$ and Perniö. The oak sculpture of the Resurrected Christ from Nousiainen ${ }^{64}$ also attributed to the Master of Lieto, can hardly originate from one and the same workshop (Fig. 5): the division of the mass and volume of the cloak are more balanced in the Nousiainen sculpture, in addition to its more natural posture. The feet with crooked toes point slightly to the sides, whereas Christ from Raisio seems to lean forward, and his toes point forward. Nevertheless, the draperies in Raisio are skilfully carved, forming a layered composition. A notable difference is the triangular side wound is exceptionally large in the sculpture from Nousiainen, but in the Raisio sculpture the wound is much smaller and shallower. It seems that whatever the liturgical or devotional motivation for the spacious wound may have been, it had not been taken into account by the time the Resurrected Christ in Raisio was created.

To sum up, the differences in artistic and technical quality among the standing Virgins, as well between the Resurrected Christs from Raisio and Nousiainen described above, possibly indicate that two workshops with carvers/painters with different levels of experience and skills have been involved in their manufacture and that in some cases oak sculptures may have been used as models. The workshop/ carvers responsible for the alder sculptures knew of the material's good qualities: alder is a solid, wax-like material, with a plasticity that allows the carver to achieve relatively complicated, three-dimensional forms. However, numerous insect holes and severe splitting in many

61 Nordman, Medeltida skulptur i Finland, 63. Inv. nr. TM190:13, height $90 \mathrm{~cm}$.

62 Conservation Report 'Ylösnoussut Kristus, Raisio', National Museum of Finland, Conservation Archive.

63 Conservation Report 'Madonna, Hattula', National Museum of Finland, Conservation Archive.

64 Nordman, Medeltida skulptur i Finland, 162-163. Inv. nr. 2073:4, height $148 \mathrm{~cm}$. 


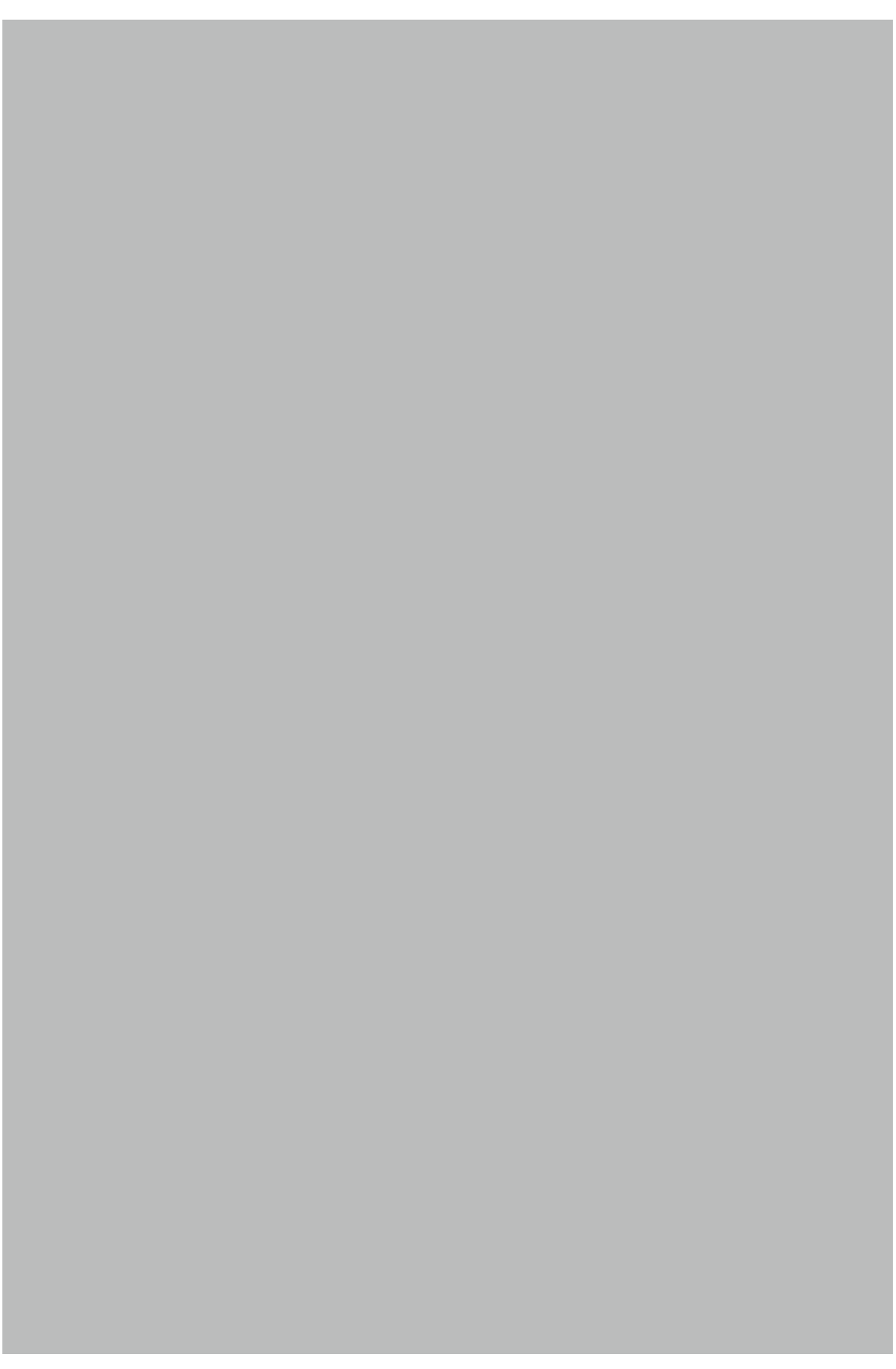

FIG. 5. RESURRECTED CHRIST FROM NOUSIAINEN CHURCH. OAK, 1320-1350. NATIONAL MUSEUM OF FINLAND. PHOTO: ILARI JÄRVINEN, FINNISH HERITAGE AGENCY. of the alder sculptures speak of poorer durability of this material. It is plausible that alder (and other locally available hardwood species) may have been used for figure sculpting to a much larger extent than can be deduced on the basis of the surviving corpus.

\section{LIMEWOOD SCULPTURES}

Along with oak and alder, the Master of Lieto group features limewood sculptures: the skilfully carved, elegant St. John the Baptist from Taivassalo, ${ }^{65}$ dressed in a long robe and a tunic with a U-shaped collar and with symmetrically layered thin folds on the front; a small apostle from Lieto ${ }^{66}$ with roughly carved facial features repeating the form of the Taivassalo St. John, but dressed in a tunic with sharpshaped folds and a V-shaped neckline; the Crucifix in Taivassalo church with an exceptionally fine but fragmented polychromy. ${ }^{67}$

In general, the number of limewood sculptures first seems to increase at the beginning of the 15th century, when the first tabernacles and altarpieces with multiple figures were purchased from East Prussia to the diocese. The amount of these imports is probably much larger than previously thought, because until recently many of the individual sculptures were believed to be made from birch and thus interpreted as manufactured in local workshops. Further wood anatomical analysis has to be carried out to enable us to paint an overall picture of the developments in the 15th century, but on the basis of the results gained thus far it seems that local workshops also used limewood. This concerns to all the sculptures in the collection of the National Museum attributed to the Master of Sääksmäki and the alterations made "in the same workshop style" to

65 Inv. nr. H2717:1, height $100 \mathrm{~cm}$; Tuuli Timonen, Liedon ja Sääksmäen mestareille attribuoitujen veistosten puиanatominen tutkimus. Tutkimusraportt1 (Kasvimuseo, Luonnontieteellinen keskusmuseo, 22 June 1999). National Museum of Finland, Conservation Archive.

66 Inv. nr. TMM4819, height $71 \mathrm{~cm}$; Mia Lempiäinen-Avci, Keskiaikaisten veistosten puuaineen määritys. Tutkimusraportti (University of Turku, Department of Biology, Herbarium / Archaeobotanical laboratory, 2015).

67 See Mirja-Liisa Waismaa-Pietarila, 'Triumfkrusifixet i Tövsala kyrka och dess konservering', Finskt museum 1981, 88. årgången, ed. by Torsten Edgren (Helsingfors: Finsk fornminnesförening, 1983), 43-57; Nordman, Medeltida skulptur i Finland, 169-171. 
a 13th century Virgin Mary and Child. ${ }^{68}$ Preliminary examination of a sculpture of St. James the Elder from Somero, attributed to another local carver whom C. A. Nordman calls the Master of Korppoo, also seems to point to limewood. ${ }^{69}$

In the group of sculptures attributed to the Master of Lieto, the limewood sculpture of St. John seems to relate stylistically, formally, and by its high technical level of execution to many oak sculptures, such as the apostles St. Peter and St. Paul from Lieto, St. James the Elder, and the above-mentioned Resurrected Christ from Nousiainen. ${ }^{70}$ These sculptures have been purchased for congregations and churches in the vicinity of Turku, which may indicate that the artworks were also manufactured in Turku. This would mean that the workshop in question utilized both limewood and oak in its production. The small apostle from Lieto mentioned in the beginning of this chapter could, on account of its less skilful technical execution, be a 15th century interpretation of the "workshop style" of the five presented sculptures.

The new results regarding wood species do not completely reduce the speculative character of the workshop attributions based on style analysis, as these examples have demonstrated. The questions who made the sculptures and where, remain unsolved in many cases, at least to date. The international Gothic style was followed by the journeymen who created their own versions of it, and so it is therefore difficult to define the "nationalities" of these craftsmen or the character of their production. As an example, the above-named oak sculptures of the apostles of St. Peter and St. Paul from Lieto seem to share stylistic features with many of the artworks in Gotland dating from the first part of the 14th century, such as the altarpiece

68 Inv. nr. H4563:1, height $78 \mathrm{~cm}$. For a report on the wood anatomical analysis, see Timonen, Liedon ja Sääksmäen mestareille attribuoitujen veistosten puuanatominen tutkimus. Tutkimusraportti; Carl Axel Nordman, 'Urdialaskåpet och Sääksmäkimästaren', Finskt Museum (Helsingfors: Finska Fornminnesföreningen, 1949), 34-51; Elina Räsänen has dated the production of the Master of Sääksmäki to around 1470 rather than to around 1450, as suggested by Nordman. Räsänen, Ruumiillinen esine, materiaalinen suku, 196, 205, 206.

69 The wood of the James the Elder (H1180:6, height $83 \mathrm{~cm}$ ) was defined by eye by the sculpture for the exhibition Pyhät ja pakanat. Ihmisyyden kuvia in Häme castle, produced by the National Museum, see Pyhät ja pakanat. Ihmisyyden kuvia, 95; see also Nordman, Medeltida skulptur $i$ Finland, 529.

70 Inv. nr. TMM4821 (Peter), height $84 \mathrm{~cm}$; Inv. nr. TMM4820 (Paul), height $83 \mathrm{~cm}$; Inv. nr 2073:2 (James), height $132 \mathrm{~cm}$. from Ganthem ${ }^{71}$, thoroughly researched by Peter Tångeberg. The paintings on the panels of the altarpiece depict a row of apostles standing on small pedestals. Even though the apostles are more vivid than the Lieto sculptures, stylistic similarities can be observed in the forms of their hair and beards, the egg-shaped faces with small mouths and large eyes, and in the forms and positions of the bodies and feet. The wood technologies used in the Ganthem altarpiece, constructed of pine panels and bars with decorative pieces of oak and another hardwood, point - according to Tångeberg - to a Gotlandic workshop. ${ }^{72}$ The workshop would have had Westphalian artwork as a model. ${ }^{73}$

\section{EXAMPLES OF SCULPTURES CONSTRUCTED FROM} SEVERAL WOOD SPECIES

The craftsmen's choices of wood were dictated by the wood's availability, and its suitability for carving, as well as by the woodworking culture the craftsmen were trained. The sculptures speak of multifaceted use of many kinds of wood. This is important to acknowledge, especially because the use of "secondary" wood species has often been interpreted as later amendments made locally, especially when these species were thought of as carved from birch. ${ }^{74}$

Many of the wooden sculptures crack during carving, especially when working with fresh wood. By removing the heartwood from a wooden figure the carvers aimed at reducing weight and preventing cracking: the heartwood shrinks more rapidly than the outer layers. To create a full-round sculpture, a separate backboard was needed to cover the hollow. However, many of these parts have not survived. Backboard and other separately added parts - such as the plugs in the drilled holes on the head and the wedges filling the cracks - were often made from other wood species than the figure itself alder or limewood seem to have been suited for these purposes. In the details of clothing - Christ's loincloths, for example - or the feet,

71 Swedish History Museum, inv. nr. SHM 11365

72 Peter Tångeberg, Retabel und Altarschreine des 14. Jahrhunderts: Schwedische Altarausstattungen in ihrem europäischen Konstext, 44-47, 64.

73 Ibidem.

74 See e.g. Nordman, Medeltida skulptur i Finland, 88, 160. 
the toes and the curls of hair - small pieces of wood were glued on to extend the material or to repair a fault in the carving. Also, the gables of the benches were often made from other wood species. Limewood was used in the hat of the oak sculpture of St. James the Elder from Nousiainen attributed to the Master of Lieto. ${ }^{75} \mathrm{~A}$ turned (limewood?) crown is placed on the head of the oaken St. Olaf from Tenhola, and a carved one on the head of the unknown female saint from Lieto. ${ }^{76}$ Alder and limewood used in one sculpture can similarly be found in the figure of St. Olaf at Luvia - the bench where he sits is carved from alder, the crown is of limewood. ${ }^{77}$ Also, the bench of a small oaken bishop from Vehmaa, ${ }^{78}$ the calf of the left leg of the oak sculpture of the Resurrected Christ from Nousiainen, ${ }^{79}$ and the backboard of the enthroned St. Olaf from Kalanti also carved from oak, are all made of alder. ${ }^{80}$

My final example, the fragmented but exquisite sculpture of the tormented body of Christ (from a crucifix) from Lieto ${ }^{81}$, illustrates how earlier research tried to find reasonable explanations to the use of various wood species and the supposed birch. Nordman, for example, suggests that due to its strong emphasis on the suffering of Christ, the sculpture in question must have been carved in the Cologne area, but the arms of birch wood - "exact copies of the original ones" were most probably carved in the Nordic countries (Fig. 6). ${ }^{82}$ The backboard and a piece of wood attached with wooden plugs to the left side of the loincloth he determines as later "reparations" made of birch. ${ }^{83}$ In fact, the sculpture, dated by Nordman to 1350-1375, is constructed of at least four different wood species: the body is carved

75 Timonen, Liedon ja Sääksmäen mestareille attribuoitujen veistosten puuanatominen tutkimus. Tutkimusraportti.

76 Inv. nr. TMM4828, height $100 \mathrm{~cm}$.

77 See note 40 .

78 Inv. nr. H4328:4, height $62.5 \mathrm{~cm}$. Timonen, Liedon ja Sääksmäen mestareille attribuoitujen veistosten puuanatominen tutkimus. Tutkimusraportti.

79 Ibidem.

80 Inv. nr. H4971, height $100 \mathrm{~cm}$. Peter Klein, Report on the dendrochronological analysis of the sculpture "St Olave" (Finland? Gotland? Inv. No. 4971), 9 September 1997. Universität Hamburg, Ordinariat für Holzbiologie. The National Museum of Finland, Conservation Archive.

81 Inv. nr. TMM4737, height $118 \mathrm{~cm}$. Turku Museum Centre.

82 Nordman, Medeltida skulptur i Finland, 189

83 Ibidem.

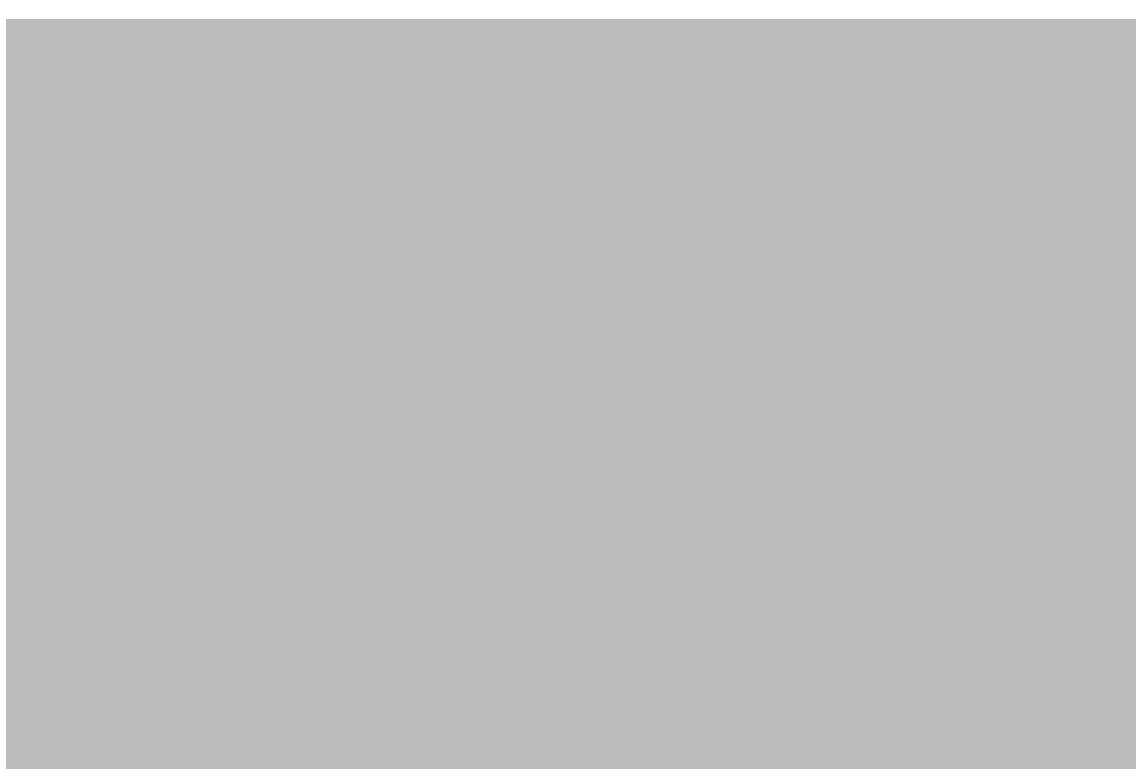

FIG. 6. THE BODY OF CHRIST FROM A CRUCIFIX FROM LIETO CHURCH. OAK, PINE, ALDER, LIMEWOOD. MIDDLE OF THE 14TH CENTURY. TURKU MUSEUM CENTRE. PHOTO: KATR

from a wedge-shaped block split radially from a block of oak, and the roughly carved backboard with clearly visible tool marks is made from alder. The delicately carved arms with stretched muscles and sinews formed in relief are of alder, whereas the wood pieces joining the arms to the body are supported by pieces of pinewood (Fig. 7). ${ }^{84}$ Lastly, the small piece of wood used to add volume to the loincloth on the left side of the body is possibly of limewood, whereas the wood piece representing withdrawn skin above the nail that pierces the right foot may well have been carved from alder.

84 Microscopic analysis was used to determine the wood of the right arm and the backboard, see Mia Lempiainen-Avci, Keskiaikaisten veistosten puuaineen määritys. Tutkimusraportti 2015. University of Turku, Department of Biology, Herbarium / Archaeobotanical laboratory. Othe wood species were determined ocularly by the author and conservators Sari Selkee and Emilia Kallinen on 17 September 2014, these wood determinations were also discussed on the basis of photos taken of the sculpture together with sculptor, Maija Helasvuo MFA and art historian Dr
Elina Räsänen in Helsinki, 22 February 2019. 


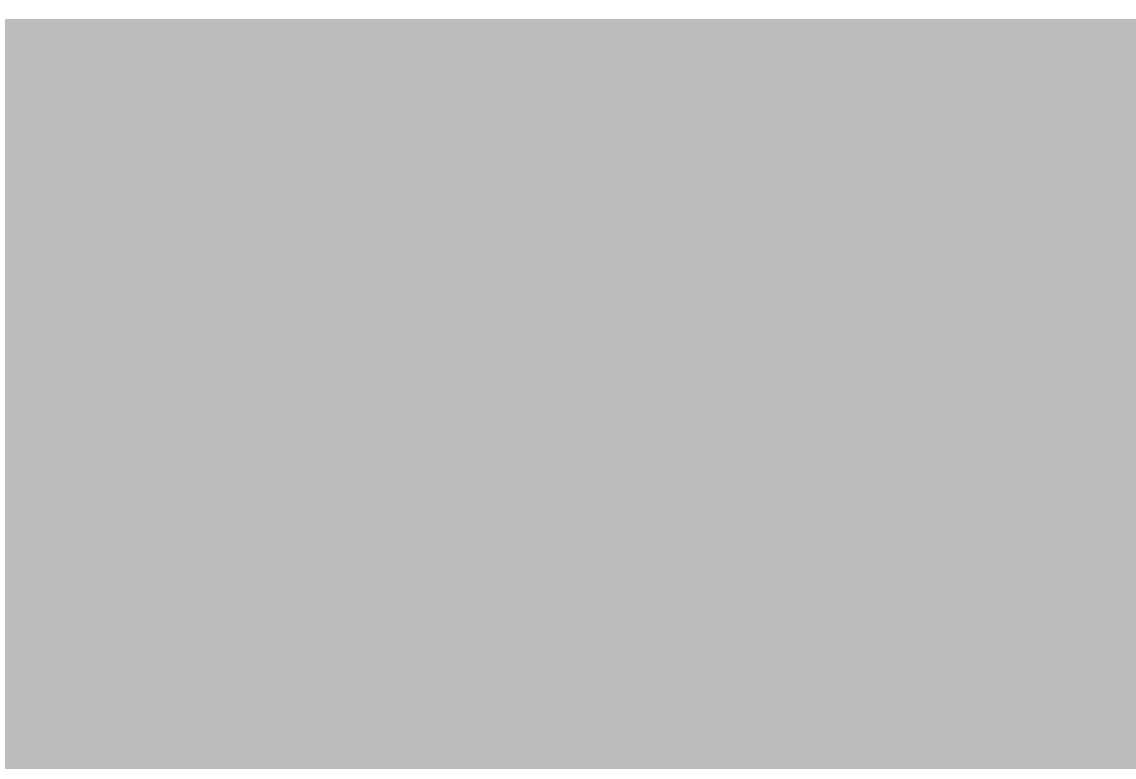

FIG. 7. THE BODY OF CHRIST FROM A CRUCIFIX FROM LIETO CHURCH: DETAIL FROM ABOVE OAK, PINE, ALDER, LIMEWOOD. MIDDLE OF THE 14TH CENTURY. TURKU MUSEUM CENTRE.
PHOTO: KATRI VUOLA.

The detailed depiction of the anatomy as well as the natural proportions of the arms resemble the quality of the carving on the legs and on the loincloth - the palms of the hands were carved separately and are now missing. According to my understanding, there is nothing that could point to a reparation. The face is less detailed, leaving the final interpretation of facial expressions to the painter. Today there is little or nothing left of the initial polychromy: some carnation (skin colour) is left between the legs and in the cavities of the face.

According to present understanding, these types of crucifixes exemplify a great number of variations and local interpretations, and their form and iconography cannot be derived directly from a certain centre. I suggest that this exquisite fragment of a sculpture has several plausible origins, because in addition to the Cologne area, the so-called Crucifixi Dolorosi can also be found e.g. in Spain, Middle
Italy and Bohemia. ${ }^{85}$ It is, however, difficult to find any counterparts for the Lieto Crucifix. The sculpture is a fine example of economical and functional use of wood, and the use of alder in a high-quality artwork. The many wood species used for its construction testify, that the sculpture must have been purchased from an area where the workshops were not as controlled as in Lübeck, as was the situation in the Hanseatic towns on the coastal areas east of Lübeck and in present-day Poland, for example.

\section{CONCLUSIONS}

The many examples of wood use in medieval sculptures in the diocese of Turku given here show how the wood use cultures of different geographical and cultural areas manifest themselves in works of art. As demonstrated, the analysis of the wood species alone is insufficient unless it is combined with analysis of the form, style and iconography of the studied sculpture. The examples of the wood use also reveal that many of the previous identifications concerning non-oaken sculptures are false: no examples of birch sculpture were found during this research. Instead another common wood species in the region, alder, seems to have been used - often by skilful craftsmen, who were aware of the wood species' suitability for carving a human figure. As many sub-species of alder grow around the Baltic Sea area and also further inland, its use cannot, automatically, be interpreted as an indication of locality. The use of different wood species in one and the same sculpture also indicates a developed woodworking culture with know-how on how different wood species can be applied to different purposes, and thus not necessarily later alterations or modern reparations

The results of this study are based on the examination of the surviving corpus of wooden sculptures in Finland and to some extent also in the neighbouring countries. The quantity of surviving material is, however, uneven: in Estonia the number of sculptures dated prior

85 On the phenomenon and the notion of the "Crucifixus Dolorosus", see Godehard Hoffmann Das Gabelkreuz in St. Maria im Kapitol zu Köln und das Phänomen der Crucifixi dolorosi in Europa, Arbeitsheft der rheinischen Denkmalpflege, 69 (Worms: Landschaftsverband Rheinland, Rheinische Amt für Denkmalpflege 2006), 15-16. 
to 1400 is today only nine; ${ }^{86}$ the surviving sculptures in Northern Germany do not provide sufficient comparative material either. ${ }^{87}$ Gotland, on the other hand, is famous for its medieval churches and the objects preserved in them, which, I believe, partly explains the eagerness to attribute sculptures in Finland to Gotlandic masters and wandering craftsmen from this island.

How do these findings, then, affect the overall picture of the origin of the ecclesiastical sculpture in the diocese of Turku? Oak and alder were the most used wood species in sculptures during the 13th and 14th centuries, but some examples of pine and lime wood sculptures can also be found in the surviving material. There is preliminary evidence of alder as a locally favoured wood species from the first half of the 14th century. Later, in the 15th century, local workshops seem to have preferred limewood rather than alder. ${ }^{88}$ The local carvers probably first used imported works from the commercial and ecclesiastical centres of Germany and Sweden as their models. Sculptures were probably also acquired from Southern Scandinavia, Norway and the Germanic lands of the coastal region of the Baltic Sea. The research has, however, to continue to achieve a more profound understanding of the different wood use cultures and craft traditions in the diocese of Turku.
Katri Vuola: Wood Species and the Question of Origin: Reassessing the Sculpture Production in the Diocese of Turku (Åbo) During the 14th Century

KEYWORDS: ART HISTORY; MEDIEVAL POLYCHROME SCULPTURE; ORIGIN; wood species; alder (Alnus); birch (Betula); bishopric of Turku (А̊во)

\section{SUMMARY}

This paper deals with choices of wood species in the 14th century polychrome sculptures in the diocese of Turku (Åbo), Finland, the easternmost part of the Swedish Realm in the Middle Ages. The aim of the article is to draw an overall picture of the wood use in sculpture and discuss the emergence of the local workshops in the diocese. This is done by presenting new wood definitions and by taking these into account the when analysing the sculptures' style and form. The emphasis on the research is on sculptures previously defined as carved from birch and which thus are determined as Finnish or Nordic of their origin. The methods for defining the wood species have been ocular observation and microscopy analysis. The choice of wood is approached from the perspective of the wood species availability in the area and suitability for carving. The results of the investigation indicate that in addition to oak, and instead of birch, particularly alder (Alnus) was used in the locally manufactured sacral sculptures, and in some cases using oak sculptures as models. Alder was possibly favored due to its good availability and inexpensiveness as well as workability. It can, however not be ruled out, that sculptures of alder may have been imported to the bishopric as well.

\section{CV}

Katri Vuola (b. 1964) is an art historian currently writing on her $\mathrm{PhD}$ at the University of Helsinki, Finland, funded by the Kone Foundation. Her thesis deals with the materiality and function of the ecclesiastical sculpture in the bishopric of Turku during the 13th and 14 th centuries. Vuola has worked as a researcher and coordinator at the museums and at the church administration. Her particular areas of interest include historiography art history research, materials and materiality of the Middle Ages, as well as museological perspectives
86 Sten Karling, Medeltida träskulptur i Estland. Kungliga Vitterhets historie och antikvitets akademien (Göteborg: Rundqvist boktryckeri 1946), 12-42.

87 See e.g. Fircks, Skulptur im Südlichen Ostseeraum. Stile, Werkstätten und Auftraggeber im 13. Jahrhundert, 9.

88 In addition to the sculptures attributed to the Master of Säksmäki, the sculpture of St. James the Elder, attributed by Nordman to the Master of Korppoo, is possibly carved from
limewood. See note 69 . 
on medieval wooden sculpture. Vuola will continue the research of the wood use in medieval sculpture in a Academy of Finland funded project Carving out Transformations (2018-2022) based at the University of Turku. Vuola is also affiliated with the Finnish Literature Society. 